\title{
Pengaruh Kepercayaan Merek terhadap Loyalitas Konsumen pada Produk Kosmetik Pixy (Studi Kasus pada Mahasiswi Universitas Samudra)
}

\author{
Meutia Dewi \\ Fakultas Ekonomi, Universitas Samudra \\ e-mail: meutiadewi@unsam.ac.id
}

\begin{abstract}
Abstrak
Penelitian ini bertujuan untuk mengetahui pengaruh kepercayaan merek (karakteristik merek, karakteristik perusahaan, dan karakteristik konsumen merek) terhadap loyalitas konsumen pada produk kosmetik Pixy. Persamaan regresi linear berganda yang dihasilkan dalam penelitian ini adalah $Y=2,866+$ $0,202 X_{1}+0,179 X_{2}+0,488 X_{3}$. Nilai koefisien determinasi $\left(R^{2}\right)$ sebesar 0,72 berarti bahwa karakteristik merek, karakteristik perusahaan, dan karakteristik konsumen merek mempengaruhi loyalitas konsumen pada produk kosmetik Pixy sebesar 72,00 \% dan sisanya 28,00 \% dipengaruhi oleh variabel lain yang tidak diteliti dalam penelitian ini. Dari hasil penelitian dapat dinyatakan bahwa variabel karakteristik merek, karakteristik perusahaan, dan karakteristik konsumen merek secara parsial berpengaruh signifikan terhadap loyalitas konsumen pada produk kosmetik Pixy. Dari hasil uji F dapat dinyatakan bahwa variabel karakteristik merek, karakteristik perusahaan, dan karakteristik konsumen merek secara simultan berpengaruh signifikan terhadap loyalitas konsumen pada produk kosmetik Pixy dapat diterima.
\end{abstract}

Kata Kunci: Kepercayaan Merk, Loyalitas, Pixy

\section{PENDAHULUAN}

Perkembangan usaha bisnis dalam era globalisasi saat ini semakin pesat ditandai dengan tingkat persaingan antar perusahaan yang semakin tinggi dan ketat. Keadaan tersebut menyebabkan perusahaan untuk memiliki keunikan tersendiri agar dapat memikat konsumen dalam rangka mempertahankan atau bahkan merebut pangsa pasar yang ada. Agar dapat bersaing di pasar, perusahaan harus terus menerus melakukan perbaikan-perbaikan atas produknya agar produk tersebut dikonsumsi bahkan digemari oleh konsumen. Sehingga tujuan perusahaan untuk dapat bertahan dan merebut pangsa pasar dapat tercapai.

Loyalitas konsumen terhadap merek produk merupakan konsep yang sangat penting khususnya pada kondisi tingkat persaingan yang sangat ketat dengan pertumbuhan yang rendah. Pada kondisi demikian, loyalitas terhadap merek sangat dibutuhkan agar perusahaan dapat bertahan hidup. Di samping itu mempertahankan loyalitas merek ini merupakan strategi yang lebih efektif dibandingkan dengan upaya menarik konsumen baru. Merek yang kuat, teruji, dan bernilai tinggi terbukti tidak hanya sukses pada hitungan rasional, tetapi juga mengelola sisi-sisi emosional konsumen. Loyalitas konsumen adalah terciptanya kepercayaan dan komitmen para konsumen terhadap suatu produk, karena mereka mendapatkan kepuasan dari produk tersebut. Keadaan seperti itu tentu sangat menguntungkan bagi perusahaan, sebab konsumen yang loyal terhadap suatu produk akan melakukan pembelian secara rutin terhadap produk tersebut.

Loyalitas konsumen terhadap suatu produk biasanya disebabkan oleh banyak faktor. Salah satu faktornya adalah kepercayaan merek yang sudah ada di benak konsumen. Variabel yang pertama terkait 
kepercayaan merek adalah karakteristik merek, merupakan faktor penting dalam menentukan pembelian konsumen untuk percaya pada suatu merek. Hal ini disebabkan konsumen melakukan perbandingan terlebih dahulu antara suatu merek produk dengan merek produk lainnya sebelum memutuskan membeli. Karakteristik ini meliputi mempunyai reputasi, dapat diramalkan, dan kompeten. Variabel yang kedua terkait kepercayaan merek adalah karakteristik perusahaan. Pengetahuan konsumen tentang perusahaan yang ada di balik merek suatu produk merupakan dasar awal pemahaman konsumen terhadap merek. Karakteristik ini meliputi reputasi suatu perusahaan, dan integritas perusahaan di balik merek tersebut. Variabel yang ketiga terkait kepercayaan merek adalah karakteristik konsumen-merek, merupakan dua kelompok yang saling mempengaruhi. Oleh sebab itu karakteristik konsumen-merek dapat mempengaruhi kepercayaan terhadap merek. Karakteristik ini meliputi kemiripan antara konsep emosional konsumen dengan kepribadian merek, kesukaan terhadap merek, dan pengalaman terhadap merek.

Salah satu produk kosmetik yang banyak diminati saat ini adalah produk kosmetik Pixy, yang merupakan salah satu produk PT. Mandom Indonesia Tbk yang diproduksi dengan lisensi dari Mandom Corporation Jepang. Merek produk Pixy merupakan salah satu produk yang memiliki nama besar di Indonesia dan sudah dikenal secara global oleh masyarakat dikarenakan melihat keberadaan produk Pixy termasuk yang cukup cepat pertumbuhan pasarnya.

Pixy memiliki prinsip dalam usahanya yaitu untuk memancarkan kecantikan khas Asia dengan membuat para wanita memiliki kulit halus, bersinar, dan sehat. Pixy memahami arti kecantikan yang sebenarnya dengan menampilkan kosmetik yang dikembangkan menurut teknologi Jepang dan semua bahan dasar kosmetik Pixy berbahan dasar alami, tidak berbahaya serta sangat baik untuk kulit wajah.

Kesetiaan konsumen tidak begitu mudah di raih oleh pihak PT. Mandom Indonesia Tbk, melainkan membutuhkan proses yang panjang untuk meyakinkan konsumen bahwa produk kosmetik Pixy merupakan produk terbaik yang di hasilkan oleh PT. Mandom Indonesia Tbk. Hal itu dapat diwujudkan dengan membangun kepercayaan terhadap konsumen.

Mahasiswi merupakan salah satu konsumen yang menggunakan produk bedak Pixy. Mereka berkeinginan untuk selalu tampil cantik tanpa harus mengeluarkan banyak biaya, Sehingga mahasiswi merupakan pasar potensial untuk produk kosmetik Pixy. Mahasiswi Universitas Samudra merupakan salah satu konsumen produk bedak Pixy dikarenakan banyak di kalangan mahasiswi yang menggunakan produk bedak Pixy. Untuk itu peneliti menilai bahwa mahasiswi Universitas Samudra adalah subyek yang tepat untuk dijadikan penelitian.

Berdasarkan penelitian pendahuluan yang dilakukan pada mahasiswi Universitas Samudra dari 20 orang mahasiswi, 14 orang menyatakan bahwa loyalitas mereka terhadap produk bedak Pixy dikarenakan produk bedak Pixy mampu memenuhi harapan dan memberikan jaminan kualitas pada setiap penggunaannya serta diproduksi oleh perusahaan yang memiliki reputasi sehingga menimbulkan kepercayaan terhadap kosmetik Pixy. Akan tetapi 6 mahasiswi lainnya menyatakan bahwa terdapat beberapa merek kosmetik lain yang saat ini lebih baik dari Pixy.

Berdasarkan rumusan masalah di atas, maka tujuan dari penelitian ini adalah:

1. Untuk mengetahui pengaruh kepercayaan merek (karakteristik merek, Karakteristik perusahaan, dan karakteristik konsumenmerek) secara parsial terhadap loyalitas konsumen pada produk kosmetik Pixy.

2. Untuk mengetahui pengaruh kepercayaan merek (karakteristik merek, karakteristik perusahaan, dan karakteristik konsumenmerek) secara simultan terhadap loyalitas konsumen pada produk kosmetik Pixy.

\section{Pengertian Merek}

Menurut Kotler dan Keller (2009), merek adalah nama, istilah, lambang atau desain, atau kombinasinya, yang dimaksudkan untuk mengidentifikasi barang 
atau jasa dari seorang atau kelompok penjual dan untuk membedakannya dari produk pesaing. Alma (2014:147) menyatakan bahwa merek adalah suatu tanda atau simbol yang memberikan identitas suatu barang atau jasa tertentu yang dapat berupa kata-kata, gambar atau kombinasi keduanya. Sedangkan Simamora (2007) menjelaskan bahwa merek adalah segala sesuatu yang mengidentifikasikan barang atau jasa penjual dan membedakannya dari barang dan jasa lainnya.

\section{Pengertian Kepercayaan Merek}

Menurut Delgado (Ferrinadewi, 2008), kepercayaan merek merupakan harapan akan kehandalan dan intensi baik terhadap merek. Lau dan Lee (Tjiptono, 2006) berpendapat bahwa kepercayaan terhadap merek (trust in a brand) adalah kemauan konsumen mempercayai merek dengan segala resikonya, karena ada harapan bahwa merek tersebut dapat memberikan suatu hasil yang positif baginya.

Berdasarkan uraian diatas, dapat disimpulkan bahwa kepercayaan merek adalah persepsi akan keterhandalan suatu merek tertentu dari sudut pandang konsumen, yang diikuti dengan kesediaan untuk mempercayai atau mengandalkan merek (nama, istilah, simbol, desain, atau gabungan keempatnya) tersebut.

\section{Indikator Kepercayaan Merek}

Menurut Lau dan Lee (Sugiarto, 2005), kepercayaan merek (trust in a brand) memiliki tiga konsep variabel, yaitu sebagai berikut:

$\begin{array}{lrr}\text { 1. Karakteristik } & \text { merek } & \text { (brand } \\ \text { characteristic) } & \text { berkaitan } & \text { dengan }\end{array}$
kepercayaan

konsumen terhadap suatu merek. Kepercayaan di sini menyangkut tentang kinerja merek yang dapat diramalkan, mempunyai reputasi dan kompetensi merek, dengan indikator:

a. Merek dengan reputasi tinggi, yaitu dengan kualitas yang baik dan mampu bersaing dengan merek lain.

b. Pengetahuan publik tentang merek, yaitu suatu tingkat pengetahuan masyarakat terhadap suatu merek.

c. Berita positif tentang merek produk, yaitu suatu kabar berita yang baik tentang produk di masyarakat.

d. Pengetahuan konsumen tentang merek yaitu tingkat pengetahuan konsumen mengenai merek yang telah digunakan.

e. Kinerja merek dapat diantisipasi, yaitu tingkat keefektisan suatu perusahaan terhadap merek, sehingga dalam pelaksanaannya dapat berjalan dengan baik.

f. Merek yang konsisten dengan kualitas yaitu tingkat konsistensi suatu merek dengan menjaga kualitas yang sesuai dengan keinginan masyarakat.

g. Harapan konsumen terhadap merek, yaitu suatu keinginan konsumen terhadap apa yang dilakukan perusahaan pada produk yang dipasarkannya.

h. Berbeda dengan merek lain, yaitu perbandingan dengan merek ataupun produk merek lain dengan bidang yang sama yang memiliki kekuatan merek yang berbeda.

i. Efektivitas produk dibandingkan dengan merek lain, yaitu perbandingan tingkat kinerja yang ditawarkan suatu perusahaan terhadap produk yang dipasarkannya.

j. Merek yang paling dapat memenuhi kebutuhan, yaitu suatu produk yang memiliki kekuatan yang baik dan dapat memenuhi kebutuhan masyarakat.

2. Karakteristik perusahaan (Company Characteristic) yang ada di balik merek akan berpengaruh terhadap loyalitas merek, karakteristik perusahaan merupakan dasar awal pemahaman konsumen terhadap suatu produk. Karakteristik ini meliputi reputasi suatu perusahaan serta integritas perusahaan di balik merek tersebut, dengan indikator:

a. Kepercayaan terhadap perusahaan, yaitu suatu tingkat kepercayaan konsumen ataupun pelanggan terhadap perusahaan. 
b. Perusahaan tidak akan menipu pelanggan, merupakan suatu komitmen yang di pegang teguh oleh suatu perusahaan agar menciptakan loyalitas konsumen.

c. Perhatian perusahaan terhadap pelanggan, merupakan salah satu wujud strategi pemasaran agar masyarakat merasakan kenyamanan dalam menggunakan produk suatu perusahaan.

d. Keyakinan pelanggan terhadap produk perusahaan, merupakan wujud dari hasil suatu komitmen untuk melayani konsumennya.

3. Karakteristik

\section{(Consumer-brand}

konsumen-merek

merupakan totalitas pemikiran dan perasaan individu dengan acuan dirinya sebagai obyek sehingga sering kali dalam konteks pemasaran dianalogkan merek sama dengan orang. Konsumen sering kali berinteraksi dengan merek seolah-olah merek tersebut adalah manusia sehingga kesamaan antara konsep diri konsumen dengan merek dapat membangun kepercayaan terhadap merek. karakteristik konsumen-merek dapat mempengaruhi kepercayaan terhadap merek. Karakteristik ini meliputi kemiripan antara konsep emosional konsumen dengan kepribadian merek, kesukaan terhadap merek dan pengalaman terhadap merek, dengan indikator:

a. Ada kesamaan merek dengan emosi pelanggan, yaitu antara perusahaan dengan konsumen memiliki keinginan dan tujuan yang sama.

b. Merupakan merek favorit, yaitu persepsi konsumen akan suatu merek yang diinginkan tentunya dengan kualitas yang baik.

c. Merek yang sesuai dengan kepribadian pelanggan, merupakan suatu persepsi konsumen akan merek suatu produk yang digunakan.

\section{Pengertian Loyalitas konsumen}

Menurut Griffin (2007), loyalitas adalah pembentukan sikap dan pola perilaku seseorang konsumen terhadap pembelian dan penggunaan produk yang merupakan hasil dari pengalaman mereka sebelumnya. Sedangkan menurut Karsono (2008), loyalitas konsumen adalah suatu komitmen yang mendalam untuk membeli kembali atau berlangganan suatu produk atau jasa secara konsisten di masa yang akan datang sehingga dapat menyebabkan pengulangan pembelian produk yang sama walaupun ada pengaruh situasi dari berbagai usaha pemasaran yang berpotensi untuk menyebabkan tindakan perpindahan merek produk.

Griffin (2007) menyimpulkan bahwa perilaku pembelian dalam diri seorang konsumen yang loyal menunjukkan kesamaan pada empat sifat, yaitu pembelian secara berulang, pembelian produk dari perusahaan yang sama, anjuran kepada orang lain untuk menggunakan produk yang sama, serta kecenderungan mengabaikan produk kompetitor.

\section{Manfaat Loyalitas Konsumen}

Griffin (2007) menyatakan bahwa manfaat yang diperoleh perusahaan apabila mempunyai konsumen yang loyal yaitu sebagai berikut:

1. Dapat mengurangi biaya pemasaran

Biaya pemasaran akan lebih murah dalam mempertahankan konsumen yang lama, apabila dibandingkan dengan upaya untuk menarik dan mendapatkan konsumen yang baru.

2. Dapat meningkatkan volume perdagangan

Loyalitas yang kuat terhadap suatu merek akan menghasilkan peningkatan penjualan serta memperkuat keyakinan perantara pemasaran, sehingga dapat memperbesar pangsa perusahaan.

3. Dapat menarik minat bagi konsumen baru

Konsumen dari suatu merek yang merasa puas dan suka pada suatu merek akan menimbulkan perasaan yakin bagi calon konsumen yang baru untuk mengkonsumsi suatu merek, terutama jika pembelian yang mereka lakukan mengandung resiko yang tinggi. 
4. Dapat mengurangi biaya turn over konsumen. Hal ini disebabkan karena tingkat penggantian konsumen akan menjadi lebih sedikit.

5. Dapat memberi waktu untuk merespon ancaman dari produk perusahaan saingan. Loyalitas merek akan memberikan waktu pada sebuah perusahaan untuk merespon gerakan pesaing.

6. Dapat mengurangi biaya kegagalan, seperti biaya penggantian produk, dan lain-lain.

7. Dapat mendorong word of mouth yang lebih positif, dengan asumsi bila konsumen loyal berarti mereka merasa puas terhadap produk tersebut.

\section{Faktor-Faktor yang Mempengaruhi Loyalitas Konsumen}

Menurut Nugroho (2005), faktor-faktor yang mempengaruhi loyalitas konsumen adalah sebagai berikut:

1. Kepuasan (satisfaction)

Konsumen akan loyal terhadap suatu produk bila ia mendapatkan kepuasan dari produk tersebut. Karena itu, bila konsumen mencoba beberapa macam produk melampaui kriteria kepuasan produk, maka akan diketahui apakah konsumen merasa puas atau tidak. Bila setelah mencoba dan responnya baik, berarti konsumen tersebut puas sehingga akan memutuskan membeli produk tersebut secara konsisten sepanjang waktu.

2. Perilaku kebiasaan (habitual behavior)

Kesetiaan konsumen dapat di bentuk karena kebiasaan konsumen. Apabila yang dilakukan sudah merupakan kebiasaan, maka pembeli tersebut tidak lagi melalui pengambilan keputusan yang panjang. Pada kondisi ini dapat dikatakan bahwa konsumen akan tetap membeli produk tersebut, yaitu konsumen akan membeli produk yang sama untuk suatu jenis produk dan Cenderung tidak berganti-ganti produk.

3. Komitmen (commitment)

Kesetiaan konsumen akan timbul bila ada kepercayaan dari konsumen terhadap produk-produk sehingga ada komunikasi dan interaksi di antara konsumennya.

4. Kesukaan produk (linking of the brand) Tingkat kesetiaan konsumen dapat diukur mulai dari timbulnya kesukaan terhadap produk sampai ada kepercayaan dari produk tersebut berkenaan dari kinerja produk-produk tersebut. Konsumen yang loyal adalah konsumen yang berulang kali membeli produk bukan karena adanya penawaran khusus, tetapi konsumen percaya pada produk tersebut memiliki kualitas yang sama sehingga memberikan tingkatan sama pada produknya.

5. Biaya pengalihan (switching cost) Adanya perbedaan pengorbanan dan atau resiko kegagalan, biaya, energi, dan fisik yang dikeluarkan konsumen karena dia memilih salah satu alternatif. Bila biaya pengalihan besar, maka konsumen akan berhati-hati untuk berpindah ke produk lain karena resiko kegagalan yang juga besar sehingga konsumen cenderung loyal.

\section{METODE PENELITIAN Jenis dan Sumber Data}

Jenis data yang digunakan dalam penelitian ini ada dua yaitu:

1. Data kualitatif yaitu data yang tidak dapat diukur dengan skala numerik atau data yang bersifat teori-teori (Lungan, 2006). Data kualitatif dalam penelitian ini yaitu landasan teori dan gambaran umum obyek penelitian.

2. Data Kuantitatif yaitu data yang dapat diukur dengan suatu skala numerik atau angka (Lungan, 2006). Data kuantitatif dalam penelitian ini adalah skor kuesioner yang telah di isi oleh mahasiswi Universitas Samudra.

Sumber data yang digunakan dalam penelitian ini ada dua yaitu:

1. Data primer merupakan data yang diperoleh secara langsung dari sumber asli atau obyek penelitian (Lungan, 2006) . Pada penelitian ini data primer diperoleh dari hasil wawancara, observasi, dan pembagian kuesioner kepada mahasiswi 
Universitas Samudra untuk mendapatkan data yang terkait dengan penelitian ini.

2. Data sekunder merupakan data yang diperoleh secara tidak langsung melalui media perantara diperoleh atau dicatat oleh pihak lain (Lungan, 2006). Data sekunder dalam penelitian ini yaitu dari buku-buku, internet, jurnal-jurnal, hasil-hasil penelitian terdahulu, dan berbagai sumber lain yang berisikan informasi dan teori-teori yang berkaitan dengan penelitian ini.

\section{Populasi dan Sampel}

Menurut Sugiyono (2012), populasi diartikan sebagai wilayah generalisasi yang terdiri atas obyek/subyek yang mempunyai kualitas dan karakteristik tertentu yang ditetapkan oleh peneliti untuk dipelajari dan kemudian ditarik kesimpulannya. Populasi dalam penelitian ini adalah Mahasiswi Universitas Samudra yang merupakan konsumen produk kosmetik bedak Pixy, yang tidak diketahui jumlahnya secara pasti.

Sampel adalah sebagian dari jumlah dan karakteristik yang dimiliki oleh populasi tersebut (Sugiyono, 2012). Pertimbanganpertimbangan yang digunakan dalam menentukan sampel adalah karena jumlah konsumen tidak teridentifikasi, maka penentuan sampel dilakukan dengan metode non probability sampling, dengan teknik accidental sampling. Aksidental sampling adalah teknik pengumpulan sampel berdasarkan kebetulan, yaitu siapa saja yang secara kebetulan bertemu dengan peneliti dapat digunakan sebagai sampel, bila dipandang yang kebetulan ditemui itu cocok sebagai sumber data (Sugiyono, 2012).

Jumlah populasi dalam penelitian ini tidak diketahui secara pasti berapa jumlahnya, sehingga penentuan jumlah sampel juga tidak akurat. Oleh karena itu, menurut Sarwono (2011), untuk menentukan jumlah sampel dalam penelitian ini maka digunakan rumus cochran sebagai berikut (dengan asumsi $\mathrm{p}=$ 0,5 , tingkat kepercayaan sebesar $95 \%$ dan presisi $\pm 10 \%)$ :

$\mathrm{n}_{0}=\frac{Z^{2} p \cdot q}{e^{2}}$

$$
\begin{aligned}
& =\frac{(1,96)^{2}(0,5)(0,5)}{(0,1)^{2}} \\
& =96 \text { orang }
\end{aligned}
$$

Jadi jumlah sampel dalam penelitian ini yaitu sebanyak 96 responden.

Keterangan :

$\mathrm{n}_{0} \quad=$ ukuran sampel

$\mathrm{Z}^{2}=$ abscissa kurva normal yang memotong area sisi (tails), atau 1tingkat

kepercayaan, misalnya 95\% dalam tabel ditemukan 1,96

$\mathrm{e} \quad=$ tingkat kepercayaan yang diinginkan

$\mathrm{p} \quad=$ proporsi yang diestimasi suatu atribut yang ada dalam suatu populasi

$\mathrm{q}=1-\mathrm{p}$

\section{Metode Pengumpulan Data}

Teknik pengumpulan data dalam penelitian ini meliputi:

1. Penelitian lapangan (Field Research), meliputi:

a. Observasi adalah metode atau caracara pengumpulan data dengan menganalisis dan mengadakan pencatatan secara sistematis mengenai tingkah laku dengan mengamati individu secara langsung (Sugiyono, 2012). Observasi dalam penelitian ini dengan cara mengamati secara langsung mahasiswi Universitas Samudra yang menggunakan produk bedak Pixy.

b. Wawancara adalah pertemuan dua orang untuk bertukar informasi dan ide melalui tanya jawab sehingga dapat dikonstruksikan makna dalam suatu topik tertentu (Sugiyono, 2012). Wawancara dalam penelitian ini dilakukan dengan cara tatap muka dan tanya jawab langsung dengan mahasiswi Universitas Samudra untuk mengetahui pendapat mereka mengenai kepercayaan merek pada produk kosmetik Pixy.

c. Kuesioner adalah metode pengumpulan data dengan menyebarkan daftar pernyataan tertulis kepada responden 
tentang obyek yang sedang diteliti Sugiyono, 2012). Kuesioner pada penelitian ini disebarkan kepada responden produk kosmetik Pixy yaitu mahasiswi Universitas Samudra untuk menjawab pernyataan dengan skala pengukuran menggunakan skala likert, dengan metode skoring sebagai berikut: Skor 5 untuk jawaban Sangat Setuju (SS)

Skor 4 untuk jawaban Setuju (S)

Skor 3 untuk jawaban Kurang Setuju $(\mathrm{KS})$

Skor 2 untuk jawaban Tidak Setuju (TS)

Skor 1 untuk jawaban Sangat Tidak Setuju (STS)

Kuesioner pada penelitian ini di adopsi dari penelitian Wulan (2014).

2. Penelitian Kepustakaan (Library Research) merupakan pengumpulan data secara teoritis dengan cara menelaah buku-buku, internet, jurnal-jurnal, hasilhasil penelitian terdahulu, dan berbagai sumber lain yang berisikan informasi dan teori-teori yang berkaitan dengan penelitian ini.

\section{Metode Analisis Data}

Metode analisis data merupakan alat yang digunakan dalam memecahkan masalah. Dalam penulisan ini digunakan metode analisis data yaitu regresi linear berganda yang digunakan untuk menguji pengaruh atau hubungan antara variabel independen (karakteristik merek, karakteristik perusahaan, dan karakteristik konsumen-merek) dengan variabel dependen (loyalitas konsumen). Perhitungan akan dilakukan dengan menggunakan komputerisasi program SPSS (Statistical Package for Social Science), Versi 17 for windows. Menurut Sugiyono (2012), persamaan regresi linear berganda adalah sebagai berikut:

$$
\mathrm{Y}=\alpha+\beta_{1} \mathrm{X}_{1}+\beta_{2} \mathrm{X}_{2}+\ldots \ldots . .+\beta_{\mathrm{n}} \mathrm{X}_{\mathrm{n}}
$$

Keterangan :

$\mathrm{Y}=$ Variabel dependen

$\alpha=$ Konstanta

$\beta=$ Koefisien regresi

$\beta_{\mathrm{n}}=$ Koefisien regresi yang ke- $\mathrm{n}$

$\mathrm{X}=$ Variabel independen
$\mathrm{X}_{\mathrm{n}}=$ Variabel independen yang ke- $\mathrm{n}$

$\mathrm{e}=$ Errorterm

Adapun persamaan regresi linear berganda dalam penelitian ini selanjutnya ditransformasi ke model persamaan yaitu sebagai berikut:

$$
\mathrm{Y}=\alpha+\beta_{1} \mathrm{X}_{1}+\beta_{2} \mathrm{X}_{2}+\beta_{3} \mathrm{X}_{3}
$$

Keterangan :

$\mathrm{Y}=$ Loyalitas Konsumen

$\alpha=$ Bilangan Konstanta

$\beta_{1}=$ Koefisien Regresi dari Variabel Karakteristik Merek

$\beta_{2}=$ Koefisien regresi Variabel Karakteristik Perusahaan

$\beta_{3}=$ Koefisien Regresi dari Variabel Karakteristik Konsumen-Merek

$\mathrm{X}_{1}=$ Karakteristik Merek

$\mathrm{X}_{2}=$ Karakteristik Perusahaan

$\mathrm{X}_{3}=$ Karakteristik Konsumen-Merek

\section{HASIL ANALISIS}

Hasil analisis statistik mengenai pengaruh kepercayaan merek terhadap loyalitas konsumen pada produk Pixy, dirangkum pada tabel 1. Dari tabel 1 dapat dibuat persamaan regresi linear berganda sebagai berikut $\mathrm{Y}=2,866+0,202 \mathrm{X}_{1}+$ $0,179 \mathrm{X}_{2}+0,488 \mathrm{X}_{3}$.

1. Konstanta sebesar 2,866 adalah nilai variabel loyalitas konsumen jika variabel bebas (karakteristik merek, karakteristik perusahaan, dan karakteristik konsumen merek) bernilai nol.

2. Nilai koefisien regresi variabel karakteristik merek sebesar 0,202 menunjukkan pengaruh positif terhadap loyalitas konsumen dan jika ditingkatkan sebesar satu satuan maka akan meningkatkan loyalitas konsumen pada produk kosmetik Pixy sebesar 0,202 dengan asumsi variabel karakteristik perusahaan dan karakteristik konsumen merek tetap.

3. Nilai koefisien regresi variabel karakteristik perusahaan sebesar 0,179 menunjukkan pengaruh positif terhadap loyalitas konsumen dan jika ditingkatkan sebesar satu satuan maka akan meningkatkan loyalitas konsumen pada 
Tabel 1. Hasil Analisis Statistik

\begin{tabular}{|c|c|c|c|c|}
\hline Variabel & & $\mathrm{B}$ & $\mathrm{t}$ & Sig.t \\
\hline Konstanta & & 2.866 & 2.106 & 0.038 \\
\hline Karakteristik Merek & & 0.202 & 2.531 & 0.013 \\
\hline Karakteristik Perusahaan & & 0.179 & 2.240 & 0.027 \\
\hline Karakteristik Konsumen Merek & & 0.488 & 5.049 & 0.000 \\
\hline Adjusted R Square & $=$ & 0.720 & & \\
\hline $\mathrm{F}$ & $=$ & 82.602 & & \\
\hline Sig. F & $=$ & 0.000 & & \\
\hline
\end{tabular}

Sumber : Data Primer diolah, 2017

produk kosmetik Pixy sebesar 0,179 dengan asumsi variabel karakteristik merek dan karakteristik konsumen merek tetap.

4. Nilai koefisien regresi variabel karakteristik konsumen merek sebesar 0,488 menunjukkan pengaruh positif terhadap loyalitas konsumen dan jika ditingkatkan sebesar satu satuan maka akan meningkatkan loyalitas konsumen pada produk kosmetik Pixy sebesar 0,488 dengan asumsi variabel karakteristik merek dan karakteristik perusahaan tetap.

\section{Koefisien Determinasi $\left(\mathbf{R}^{2}\right)$}

Koefisien determinasi digunakan untuk mengetahui pengaruh variabel independen terhadap variabel dependen. Berdasarkan tabel 1 memperlihatkan hasil koefisien determinasi $\left(\mathrm{R}^{2}\right)$ yang diperoleh dari kolom Adjusted R Square dengan nilai sebesar 0,720 yang dapat dinyatakan bahwa variabel karakteristik merek, karakteristik perusahaan, dan karakteristik konsumen merek memberikan pengaruh terhadap variabel loyalitas konsumen pada produk kosmetik Pixy sebesar $72,00 \%$ dan sisanya $28,00 \%$ dipengaruhi oleh variabel-variabel lain yang tidak di teliti dalam penelitian ini.

\section{Pembuktian Hipotesis}

Hipotesis dalam penelitian ini di uji dengan menggunakan uji statistik yang terdiri dari uji $t$ dan uji $F$.

1. Hipotesis pertama, yaitu:

a. Uji parsial untuk variabel karakteristik merek $\left(\mathrm{X}_{1}\right)$

Berdasarkan hasil perhitungan pada tabel 1 dapat diketahui bahwa nilai signifikansi untuk variabel karakteristik merek $\left(\mathrm{X}_{1}\right)$ adalah 0,013 . Nilai signifikansi ini lebih kecil dari 0,05 maka hipotesis dapat diterima, yang artinya bahwa variabel karakteristik merek $\left(\mathrm{X}_{1}\right)$ berpengaruh signifikan terhadap loyalitas konsumen (Y) pada produk kosmetik Pixy. Hal ini menjelaskan bahwa loyalitas konsumen terhadap kosmetik Pixy disebabkan oleh karakteristik merek dari produk kosmetik Pixy itu sendiri. Hasil penelitian ini sesuai dengan penelitian sebelumnya yang dilakukan oleh Riana (2010) dan Sengkey (2015) dimana hasil penelitiannya yaitu variabel karakteristik merek berpengaruh signifikan terhadap loyalitas konsumen dengan nilai signifikansi masing-masing sebesar 0,000 dan 0,006 .

b. Uji parsial untuk variabel karakteristik perusahaan $\left(\mathrm{X}_{2}\right)$

Berdasarkan hasil perhitungan pada tabel IV-8 dapat diketahui bahwa nilai signifikansi untuk variabel karakteristik perusahaan $\left(\mathrm{X}_{2}\right)$ adalah 0,027 . Nilai signifikansi ini lebih kecil dari 0,05 maka hipotesis dapat diterima, yang artinya bahwa variabel karakteristik perusahaan $\left(\mathrm{X}_{2}\right)$ berpengaruh signifikan terhadap loyalitas konsumen (Y) pada produk kosmetik Pixy. Hal ini menjelaskan bahwa loyalitas konsumen terhadap kosmetik Pixy disebabkan oleh 
karakteristik perusahaan yang menghasilkan produk kosmetik Pixy. Hasil penelitian ini di dukung oleh teori Surachman (2008), menyatakan bahwa perusahaan yang membangun inovasi untuk menjadi perusahaan inovatif yang kuat dapat membangun konsumen yang loyal melalui nilai lebih bagi konsumennya (superior consumer value). Hasil penelitian ini juga sesuai dengan penelitian sebelumnya yang dilakukan oleh Riana (2010) dan Sengkey (2015) dimana hasil penelitiannya yaitu variabel karakteristik perusahaan berpengaruh signifikan terhadap loyalitas konsumen dengan nilai signifikansi masing-masing sebesar 0,000 dan 0,000 .

c. Uji parsial untuk variabel karakteristik konsumen merek $\left(\mathrm{X}_{3}\right)$

Berdasarkan hasil perhitungan pada tabel IV-8 dapat diketahui bahwa nilai signifikansi untuk variabel karakteristik konsumen merek $\left(\mathrm{X}_{3}\right)$ adalah 0,000 . Nilai signifikansi ini lebih kecil dari 0,05 maka hipotesis dapat diterima, yang artinya bahwa variabel karakteristik konsumen merek $\left(\mathrm{X}_{3}\right)$ berpengaruh signifikan terhadap loyalitas konsumen (Y) pada produk kosmetik Pixy. Hal ini menjelaskan bahwa loyalitas konsumen terhadap kosmetik Pixy disebabkan oleh karakteristik konsumen merek dari produk kosmetik Pixy itu sendiri. Hasil penelitian ini di dukung oleh teori Lau dan Lee (Tjiptono, 2006), menyatakan bahwa untuk memperoleh loyalitas dalam pasar saat ini, pemasar harus memfokuskan pada pembentukan dan pemeliharaan kepercayaan dalam hubungan konsumen dengan merek. Hasil penelitian ini juga sesuai dengan penelitian sebelumnya yang dilakukan oleh Riana (2010) dan Sengkey (2015) dimana hasil penelitiannya yaitu variabel karakteristik konsumen merek berpengaruh signifikan terhadap loyalitas konsumen dengan nilai signifikansi masing-masing sebesar 0,000 dan 0,005 .

2. Hipotesis kedua, yaitu:

Hipotesis kedua diuji dengan Uji $\mathrm{F}$ yang hasilnya dapat dilihat pada Tabel 1 dimana menjelaskan bahwa $\mathrm{F}$ mempunyai tingkat signifikansi yaitu sebesar 0,000. Nilai signifikansi ini lebih kecil dari 0,05 maka dapat di simpulkan bahwa hipotesis dapat diterima, yang artinya bahwa variabel kepercayaan merek (karakteristik merek, karakteristik perusahaan, dan karakteristik konsumen merek) secara simultan berpengaruh signifikan terhadap loyalitas konsumen pada produk kosmetik Pixy. Hal ini menjelaskan bahwa kepercayaan merek yang sudah ada di benak konsumen dapat mempengaruhi tingkat loyalitasnya terhadap suatu produk. Konsumen kosmetik Pixy percaya pada merek bedak Pixy sehingga mereka loyal menggunakan bedak Pixy. Hasil penelitian ini di dukung oleh teori Lau dan Lee (Tjiptono, 2006), yang menyatakan bahwa kepercayaan terhadap suatu merek akan menimbulkan loyalitas konsumen terhadap merek tersebut. Hasil penelitian ini juga sesuai dengan penelitian yang di lakukan oleh Riana (2010) dan Sengkey (2015) dimana hasil penelitiannya yaitu variabel kepercayaan merek (karakteristik merek, karakteristik perusahaan, dan karakteristik konsumen merek) secara simultan berpengaruh signifikan terhadap loyalitas konsumen dengan nilai signifikansi masing-masing sebesar 0,000 dan 0,000 lebih kecil dari 0,05.

\section{KESIMPULAN DAN SARAN Kesimpulan}

Berdasarkan hasil analisis data pada penelitian ini, maka dapat disimpulkan sebagai berikut:

1. Persamaan regresi linear berganda yang diperoleh dalam penelitian ini yaitu $\mathrm{Y}=$ $2,866+0,202 X_{1}+0,179 X_{2}+0,488 X_{3}$. Konstanta sebesar 2,866 adalah nilai variabel loyalitas konsumen jika variabel bebas (karakteristik merek, karakteristik 
perusahaan, dan karakteristik konsumen merek) bernilai nol. Nilai koefisien regresi variabel karakteristik merek $\left(\mathrm{X}_{1}\right)$, karakteristik perusahaan $\left(\mathrm{X}_{2}\right)$, dan karakteristik konsumen merek $\left(\mathrm{X}_{3}\right)$ masing-masing sebesar 0,202, 0,179 dan 0,488 menunjukkan pengaruh positif terhadap loyalitas konsumen (Y).

2. Hasil koefisien determinasi $\left(\mathrm{R}^{2}\right)$ yang diperoleh dari kolom Adjusted R Square dengan nilai sebesar 0,720 yang dapat dinyatakan bahwa variabel karakteristik merek, karakteristik perusahaan, dan karakteristik konsumen merek memberikan pengaruh terhadap variabel loyalitas konsumen pada produk kosmetik Pixy sebesar $72,00 \%$ dan sisanya $28,00 \%$ dipengaruhi oleh variabel lain yang tidak di teliti dalam penelitian ini.

3. Hipotesis pertama yang menyatakan variabel karakteristik merek, karakteristik perusahaan, dan karakteristik konsumen merek secara parsial berpengaruh signifikan terhadap loyalitas konsumen pada produk kosmetik Pixy dapat di terima. Hal ini dibuktikan dari nilai signifikansi variabel karakteristik merek $\left(\mathrm{X}_{1}\right)$, karakteristik perusahaan $\left(\mathrm{X}_{2}\right)$, dan karakteristik konsumen merek $\left(\mathrm{X}_{3}\right)$ masing-masing sebesar sebesar 0,013, 0,027 dan 0,000 lebih kecil dari 0,05.

4. Hipotesis kedua yang menyatakan variabel karakteristik merek, karakteristik perusahaan, dan karakteristik konsumen merek secara simultan berpengaruh signifikan terhadap loyalitas konsumen pada produk kosmetik Pixy dapat di terima. Hal ini dibuktikan dari nilai signifikansi 0,000 lebih kecil dari 0,05.

\section{Saran}

Berdasarkan hasil penelitian ini, maka saran-saran yang dapat diberikan sebagai berikut:

1. Variabel karakteristik konsumen merek merupakan variabel yang paling dominan mempengaruhi loyalitas konsumen pada produk kosmetik Pixy oleh karena itu diharapakan bagi pihak perusahaan harus selalu memperhatikan kesamaan antara kebutuhan konsumen dengan produk yang dihasilkan. Misalnya dengan terus menciptakan inovasi-inovasi baru pada produk bedak Pixy dan mempunyai keunggulan tersendiri daripada produk bedak lain. sehingga dapat lebih meningkatkan loyalitas konsumen pada produk kosmetik Pixy.

2. Untuk penelitian selanjutnya sebaiknya variabel yang diteliti juga tidak terbatas pada kepercayaan merek saja karena masih banyak variabel lain yang dapat mempengaruhi loyalitas konsumen misalnya seperti brand image (citra merek), brand awareness (kepedulian merek), kualitas produk, harga, dan lainlain.

\section{DAFTAR PUSTAKA}

Alma, Buchari. 2014, Manajemen Pemasaran dan Pemasaran Jasa. Bandung: Alfabeta.

Ferrinadewi, Erna. 2008. Merek dan Psikologi Konsumen. Jakarta: Graha Ilmu.

Griffin, Jill. 2007. Loyalitas Pelanggan. Jakarta: Erlangga.

Karsono. 2008. Pemasaran Jasa dan Kualitas Pelayanan. Malang: Bayu Media Publishing.

Kotler, Philip dan Kevin Lane Keller. 2009. Manjemen Pemasaran. Jakarta: Gelora Aksara Pratama.

Lungan, Richard. 2006. Aplikasi Statistika dan Hitung Peluang. Yogyakarta: Graha Ilmu.

Nugroho, Setiadi. 2005. Meraih Loyalitas

Pelanggan. Jakarta: Elex Media Komputindo.

Riana, Gede. 2010. Pengaruh Trust in a Brand terhadap Consumer Loyalty pada Konsumen Air Minum Aqua di Kota Denpasar. Jurnal Manajemen dan Bisnis. Vol 13. No 2. Hal 184-202.

Sarwono, Jonathan. 2011. Mixed Methods, Cara Menggabung Riset Kuantitatif dan Riset Kualitatif Secara Benar. Jakarta: Elex Media Komputindo.

Sengkey, F. Kessy. 2015. Pengaruh Karakteristik Merek, Karakteristik Perusahaan, dan Karakteristik 
Konsumen-Merek terhadap Loyalitas Konsumen pada Produk Sepatu Bellagio di Kota Manado. Jurnal EMBA. Vol 3. No 3. Hal 341-351.

Simamora, Bilson. 2007. Membongkar

Kotak Hitam Konsumen. Jakarta:

Gramedia Pustaka Utama.

Sugiarto. 2005. Strategi Menaklukkan

Pasar Melalui Riset Ekuitas dan

Perilaku Merek. Jakarta: Gramedia Pustaka.

Sugiyono. 2012. Metode Penelitian Bisnis.

Bandung: Alfabeta.

Surachman. 2008. Dasar-Dasar Manajemen

Merek. Malang: Bayu Media

Publishing.

Tjiptono, Fandy. 2006. Pemasaran Jasa.

Malang: Bayu Media Publishing. 